\title{
Industrial Sustainability Index and Its Possible Improvement for Paper Industry
}

\author{
Ashok Kumar Pandey, Ravi Prakash* \\ Department of Mechanical Engineering, MNNIT, Allahabad (UP), India \\ Email: akpandeygp@gmail.com, ^rprakash234@gmail.com
}

How to cite this paper: Pandey, A.K. and Prakash, R. (2018) Industrial Sustainability Index and Its Possible Improvement for Paper Industry. Open Journal of Energy Efficiency, 7, 118-128. https://doi.org/10.4236/ojee.2018.74008

Received: October 8, 2018

Accepted: December 2, 2018

Published: December 5, 2018

Copyright $\odot 2018$ by authors and Scientific Research Publishing Inc. This work is licensed under the Creative Commons Attribution International License (CC BY 4.0).

http://creativecommons.org/licenses/by/4.0/

(c) (i) Open Access

\begin{abstract}
This paper proposes a new index for assessing sustainability of the industrial sector i.e. the Industrial Sustainability Index (ISI) and demonstrates its utility by applying it to an energy intensive industry. The proposed index incorporates all the three major dimensions of sustainability viz. economic, environmental, and social. It represents the socio-economic benefit of an industry per unit of its carbon emissions. The specific energy consumption or energy intensity (with commensurate carbon emissions), which is usually reported as a measure of environmental impact of various industries, does not include the social and economic parameters. The proposed ISI also overcomes the difficulties in assessing specific energy consumption such as allocation in case of multiple products and its variability with the type and scale of production. To illustrate, the proposed index has been evaluated for a typical paper industry in India. Further, opportunities for its improvement by fuel substitution and repowering through combined cycle power generation have been examined. With existing ISI of 16 units to an improved ISI of 78 units, approximately five times improvement in ISI was observed, indicating a potential for significant improvement in industrial sustainability through such measures.
\end{abstract}

\section{Keywords}

Industry, Sustainability, $\mathrm{CO}_{2}$ Emissions, Industrial Sustainability Index, Socio-Economic Benefit

\section{Introduction}

Industry is one of the most important sectors of the world economy. According to the IPCC's $5^{\text {th }}$ Assessment Report [1], industry contributed nearly $21 \%$ (i.e. $15.44 \mathrm{GtCO}_{2}$ ) of the total global emissions along with $175.82 \mathrm{EJ}$ [2] as primary energy consumption in the year of 2010. Industrial systems cause and determine 
flows of materials and energy through the human economy. Although industry is often seen as a source of environmental degradation and resource depletion, it is widely recognized that it is a vital part of development and wealth creation. Therefore, as an important social factor, industry must play a prominent role in identifying and implementing more sustainable options.

Kuhn put an emphasis on the area of industrial sustainability, and stated that it is a field concerned with creating a generative, restorative and net positive economy [3]. The importance of industrial sustainability as a burgeoning field of inter-disciplinary research originates partly due to the need for gentle operation and production systems [4]. Sustainable Development Goal 9 adopted by the United Nations addresses three important aspects of sustainable development: infrastructure, industrialization and innovation. Infrastructure provides the basic physical facilities essential to business and society; industrialization drives economic growth and job creation, thereby reducing income inequality; and innovation expands the technological capabilities of industrial sectors and leads to the development of new skills [5].

Industrialization therefore touches on all the three major dimensions of sustainability i.e. economic, environmental, and social. It is therefore imperative that the sustainability assessment of the industrial sector should include all these three parameters. The conventional industrial performance indices used for assessing sustainability, such as specific energy consumption (with commensurate carbon emissions) and eco-efficiency [6], are either less comprehensive or present difficulties in evaluation such as allocation of energy use in case of multiple products and the variability of the specific energy consumption with the type and scale of production.

Paper industry is one of the five (i.e. steel, cement, ammonia, aluminum, and paper) most energy intensive industries in the world. The pulp and paper industry accounted for approximately $5 \%$ of total industrial final energy consumption and $2 \%$ of direct carbon dioxide emissions from the industrial sector globally in 2007 [7]. The Indian pulp \& paper sector accounts for about $1.71 \%$ of the world's production of paper and paperboard. The industry provides employment to more than 0.12 million people directly and 0.34 million people indirectly. The consumption of steam and electricity per ton of paper production in India is about $11-15$ ton and $1500-1700 \mathrm{kWh}$. The average specific energy consumption is estimated at $52 \mathrm{GJ} /$ ton of paper [8]. An energy survey of an Indian Paper mill [9] revealed the energy consumption in the range of $25.3-121 \mathrm{GJ} / \mathrm{ton}$ of paper. This translates to a GHG intensity range of $2.46-11.8 \mathrm{t} \mathrm{CO}_{2} /$ ton of paper produced and reinforces the diversity of operating conditions in the Indian Pulp \& Paper Mill [8]. For another process industry i.e. dairy industry in India, Prakash \& Henham analyzed the energy benefits of grid-independent Combined, Cooling, Heating \& Power (CCHP) systems, and reported primary energy savings (with commensurate carbon reduction) in the range of $20 \%$ $50 \%$ [10]. Such a study demonstrated that grid-independent co-generation sys- 
tems may lead to environmental sustainability.

Various researchers have examined industrial sustainability in different contexts [11] [12] [13] [14] [15] with the help of different parameters and studied the industrial impact. Fiksel developed a sustainability indicator approach for industrial products based on the environmental, social, and economic parameters of the product manufacturing [11]. Dickinson and Caudill [12] and Gao [13] developed the sustainability target method (STM), which is evaluated by combining the economic value of a manufactured product with their environmental impacts. Schmidt and Butt adopted a sustainability index of product (PSI), and denominated it as a management tool for sustainability assessment for the development of Ford products [14]. Ungureanu developed another method of sustainability score and used it to evaluate automobile products [15].

The above cited literature provides a rationale of assessing industrial sustainability based on social, economic, and environmental parameters. However, all the above mentioned studies are mainly related to product sustainability and may not be applicable for process industries. Further, quantitative evaluation of industrial sustainability is practically missing in the available literature. This research gap has been addressed in this paper, and a simplified methodology for quantitative evaluation of industrial sustainability has been presented. This method is equally valid for both products based (i.e. manufacturing) as well as process industries.

The work presented in this paper proposes a new holistic sustainability index for the industrial sector (integrating the social, economic, and environmental aspects of sustainability) termed as the Industrial Sustainability Index (ISI), and demonstrates its utility through a practical case study of an energy intensive paper industry.

\section{Methodology}

The Industrial Sustainability Index is proposed to satisfy social, economic and environmental goals of any industry producing any type or types of products at any scale (small, medium or large). It represents the socio-economic benefit from an industry per unit of its carbon emissions. Further, it has been formulated to easily measure the progress made by a particular industry in the direction of sustainability.

The proposed expression for ISI is as follows:

$$
I S I=\frac{(R V A) \times(E M P)}{\mathrm{CO}_{2} \text { emissions }}
$$

where,

$R V A$ is the Resource Value Addition i.e. the difference in the economic values of material \& energy outputs (products) and inputs in a year (million Rs per year).

$E M P$ is the total number of persons employed by the industry in a year.

$\mathrm{CO}_{2}$ emissions is the total carbon dioxide emissions by the industry in a year 
through its production process (tons per year).

Hence, the unit for ISI is "Million Rs Persons per ton of $\mathrm{CO}_{2}$ emission".

From the above expression, it is observed that RVA indicates the economic goal of an industry, EMP signifies the social benefit from industry, and $\mathrm{CO}_{2}$ emissions represent the environmental dimension. The desirable factors i.e. RVA and EMP are in the numerator. A higher value for these factors will indicate a higher value of ISI. Further the undesirable factor of carbon emissions is in the denominator; hence a lower value of this factor will improve the ISI and vice versa.

For the sake of simplicity, only $\mathrm{CO}_{2}$ emissions have been considered to represent the impact on global warming. It should however be replaced by $\mathrm{CO}_{2}$ equivalent to include the impact of other pollutants e.g. $\mathrm{CH}_{4}$, nitrous oxide, CFCs etc. Further, if this $\mathrm{CO}_{2}$ equivalent is represented in terms of "carbon" only, then they need to be multiplied by the factor of 0.274 [16].

It may be observed here that since RVA is in monetary terms, single or multiple outputs of an industry can all be grouped together. Such a freedom does not exist with specific energy consumption, which is specified for a particular product. In case of multiple products, the specific energy consumption evaluation is difficult because of the problem of allocation of energy use. However, the use of RVA overcomes this difficulty.

Further, while comparing the specific energy consumption, one has to take into account the scale of production i.e. small, medium or large; as the scale of production affects the specific energy consumption. For example, the RVA and $\mathrm{CO}_{2}$ emissions from a steel industry are higher than a small handicraft industry. However, the employment potential of a handicraft industry is much higher than that of a steel industry. Hence, the expression of ISI is such that it can compare any industry of any scale without prejudice.

The proposed ISI is also more comprehensive than "eco-efficiency", which may also be used as a metric for industrial sustainability [6]. The term "eco-efficiency" is a ratio of the value of a product to the environmental impact of the product. It suffers from two drawbacks: 1) it does not consider the value of the physical resource inputs, and 2) social sustainability is not addressed.

It can also be observed that the ISI is universal in nature i.e. it is independent of the product type manufactured by the industry. For example, through specific energy consumption, a cement industry can only be compared with another cement industry for bench marking. It cannot be compared with an industry, say, manufacturing textiles. However, the ISI may be used to compare any type of industry with any other type.

In a nutshell, the ISI as proposed covers the entire industrial sector under one umbrella to move in the direction of sustainable development. The ISI may be used for planning investments in the industrial sector by preferring those industries with a higher ISI. Further, tax benefits and other incentives may be provided to industries pursuing the goal of higher ISI. 


\section{Survey and Data Collection of the Pulp \& Paper Industry}

The pulp \& paper industry taken as a case study is the Orient Paper Mills (OPM) located at Amlai, Shahdol, Madhya Pradesh, India. The paper production plant has three major outputs: writing paper, tissue paper and craft paper. The raw-material input to the plant is bamboo and eucalyptus chips obtained from nearby forest. The electrical and thermal energy demands of the plant are met through a coal-fired Combined Heat \& Power (CHP) system with pass-out condensing turbine with a total capacity of $20 \mathrm{MW}$. The steam conditions at turbine inlet are $60 \mathrm{bar}, 440^{\circ} \mathrm{C}$. For heating requirements, the steam is bled from the turbines at 10.2 bar and $180^{\circ} \mathrm{C}$. The OPM unit consumes nearly $13 \mathrm{MW}$ power, while $2 \mathrm{MW}$ is imported from the grid as an emergency back-up. About $9 \mathrm{MW}$ of the electricity generated from the CHP system is exported to the adjacent chemical industry.

Figure 1 provides the process flow diagram of the paper production plant at OPM. Figure 2 provides the energy flow diagram of the plant with four paper machines, i.e. PM1 (writing paper); PM2 \& PM3 (tissue paper); and PM4 (craft paper) including the wood chipper \& pulp mill. The energy audit of the plant showed that the energy consumption of the tissue paper machines (PM2 \& PM3) was the highest, followed by that of the writing paper machine (PM1), while the craft paper machine (PM4) consumed least energy. This was because of the finer pulping requirements for the tissue paper.

Some process energy conservation measures have already been adopted in the plant such as variable frequency drives for fans and pumps, high tension capacitor bank to improve the power factor from 0.67 to 0.85 , more efficient electric motors, utilization of natural light and LED bulbs, optimized operation of boiler feed pumps etc. Such energy saving measures had payback periods less than two years and yielded energy savings of a little more than $5 \%$.

From the survey and data collection, the material and energy inputs and outputs of the OPM plant are tabulated in Table 1 . The corresponding $\mathrm{CO}_{2}$ emissions are presented in Table 2.

\section{Results \& Discussion}

To illustrate the concept and usefulness of ISI, a typical paper industry was examined. For this industry, the ISI was evaluated for the existing plant as well as after incorporating some possible modifications in the energy supply system to improve the ISI of the industry.

\subsection{ISI Evaluation for the Existing System in the Pulp \& Paper Industry}

The ISI for the OPM plant is evaluated as follows:

RVA is about 3918 million Rs, EMP is 2000 persons for the year 2017, and the total annual $\mathrm{CO}_{2}$ emissions are estimated at $489,289 \mathrm{tCO}_{2}$.

Hence, ISI for the existing system is evaluated as 16 units. 


\subsection{ISI Evaluation with Improved Energy System}

A proposal was examined to improve the existing ISI's parameters of the paper production plant through fuel substitution and "repowering". The existing coal usage is sought to be replaced by a cleaner fuel i.e. natural gas in order to reduce the carbon emissions. Further, higher efficiency of the energy supply is feasible through "repowering", which refers to the up-gradation of the existing pass-out steam turbine plant with a combined cycle plant using gas turbine as a topping unit and the existing steam turbine as a bottoming unit. For repowering, many of the existing power plant components can be used; and new investment is only required for gas turbine unit with a Heat Recovery Heat Exchanger (HRSG) as a replacement of the existing coal-fired boiler. The proposed plant is depicted in Figure 3.

The analysis of the proposed combined cycle power plant for OPM yielded the following results, which are presented in Table 3.

Table 1. Annual material and energy consumption in the existing system.

\begin{tabular}{|c|c|c|c|c|}
\hline SL. No. & $\begin{array}{c}\text { Item } \\
\text { (Input/output) }\end{array}$ & Quantity & $\begin{array}{l}\text { Price/Cost rate } \\
\text { (Rs.) }\end{array}$ & $\begin{array}{l}\text { Total Price/Cost } \\
\text { (million Rs.) }\end{array}$ \\
\hline 01 & Bamboo (input) & $97,168 \mathrm{MT}$ & $3900 / \mathrm{MT}$ & 379 \\
\hline 02 & Eucalyptus (input) & 98,925 MT & $3400 / \mathrm{MT}$ & 336 \\
\hline 03 & Coal (input) & $282,782 \mathrm{MT}$ & 3000/MT & 848 \\
\hline 04 & $\begin{array}{l}\text { Electricity from Grid } \\
\text { (input) }\end{array}$ & $17,520,000 \mathrm{kWh}$ & $6.00 / \mathrm{kWh}$ & 105 \\
\hline 05 & Furnace oil (input) & $1309 \mathrm{MT}$ & $36,000 / \mathrm{MT}$ & 47 \\
\hline 06 & High Speed Diesel (input) & $15.35 \mathrm{MT}$ & $52,000 / \mathrm{MT}$ & 0.8 \\
\hline 07 & Charcoal (input) & $0.95 \mathrm{MT}$ & $15,000 / \mathrm{MT}$ & 0.014 \\
\hline 08 & $\begin{array}{l}\text { Electricity supply to } \\
\text { adjacent chemical industry } \\
\text { (output) }\end{array}$ & $71,280,000 \mathrm{kWh}$ & $6.00 / \mathrm{kWh}$ & 428 \\
\hline 09 & $\begin{array}{l}\text { Paper production } \\
\text { (output) }\end{array}$ & $77,146 \mathrm{MT}$ & $675,000 / \mathrm{MT}$ & 5207 \\
\hline
\end{tabular}

Table 2. $\mathrm{CO}_{2}$ emissions from energy inputs in the existing system.

\begin{tabular}{|c|c|c|c|c|c|}
\hline SL.NO. & Item & Quantity & $\begin{array}{c}\text { Average Calorific } \\
\text { Value (CV) } \\
(\mathrm{MJ} / \mathrm{kg})\end{array}$ & $\begin{array}{c}\text { Specific } \\
\text { emission factor } \\
\left(\mathrm{kg} \mathrm{CO}_{2} / \mathrm{kg} \text { fuel }\right) \\
{[17]}\end{array}$ & $\begin{array}{c}\mathrm{CO}_{2} \text { Emission } \\
\left(\text { Ton } \mathrm{CO}_{2}\right)\end{array}$ \\
\hline 01 & Coal & $282,782 \mathrm{MT}$ & 17.6 & 1.66 & 469,418 \\
\hline 02 & Furnace Oil & $1309 \mathrm{MT}$ & 42.0 & 3.31 & 4331 \\
\hline 03 & $\begin{array}{l}\text { High Speed } \\
\text { Diesel }\end{array}$ & $15.35 \mathrm{MT}$ & 35.0 & 2.76 & 120 \\
\hline 04 & Charcoal & $0.95 \mathrm{MT}$ & 29.0 & 2.30 & 2.2 \\
\hline 05 & $\begin{array}{l}\text { Electricity } \\
\text { from Grid }\end{array}$ & $17,520,000 \mathrm{kWh}$ & - & $0.88 \mathrm{~kg} \mathrm{CO}_{2}$ per $\mathrm{kWh}$ & 15,418 \\
\hline
\end{tabular}


Table 3. Annual material and energy consumption in the modified system.

\begin{tabular}{|c|c|c|c|c|}
\hline $\begin{array}{l}\text { SL. } \\
\text { NO. }\end{array}$ & $\begin{array}{c}\text { Item } \\
\text { (Input/Output) }\end{array}$ & Quantity & $\begin{array}{c}\text { Price/Cost rate } \\
\text { (Rs) }\end{array}$ & $\begin{array}{l}\text { Total Price/Cost } \\
\text { (million Rs) }\end{array}$ \\
\hline 01 & Bamboo (input) & $97,168 \mathrm{MT}$ & 3900/MT & 379 \\
\hline 02 & Eucalyptus (input) & $98,925 \mathrm{MT}$ & $3400 / \mathrm{MT}$ & 336 \\
\hline 03 & Natural gas (input) & $49,363 \mathrm{MT}$ & $10,000 / \mathrm{MT}[18]$ & 494 \\
\hline 04 & Electricity supply to Grid (output) & $182,160,000 \mathrm{kWh}$ & $4.50 / \mathrm{kWh}$ & 820 \\
\hline 05 & $\begin{array}{l}\text { Electricity supply to adjacent } \\
\text { chemical industry (output) }\end{array}$ & $71,280,000 \mathrm{kWh}$ & $4.50 / \mathrm{kWh}$ & 321 \\
\hline 06 & Paper production (output) & 77,146 MT & $67,500 / \mathrm{MT}$ & 5207 \\
\hline
\end{tabular}

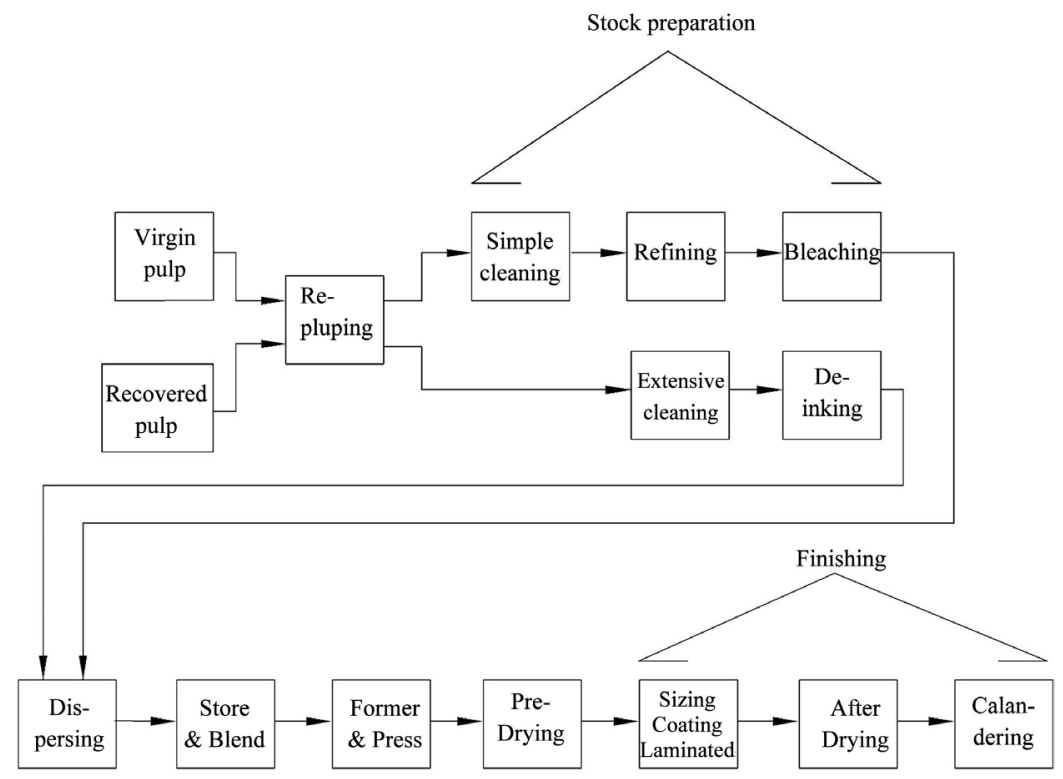

Figure 1. Process flow diagram for the paper production plant.

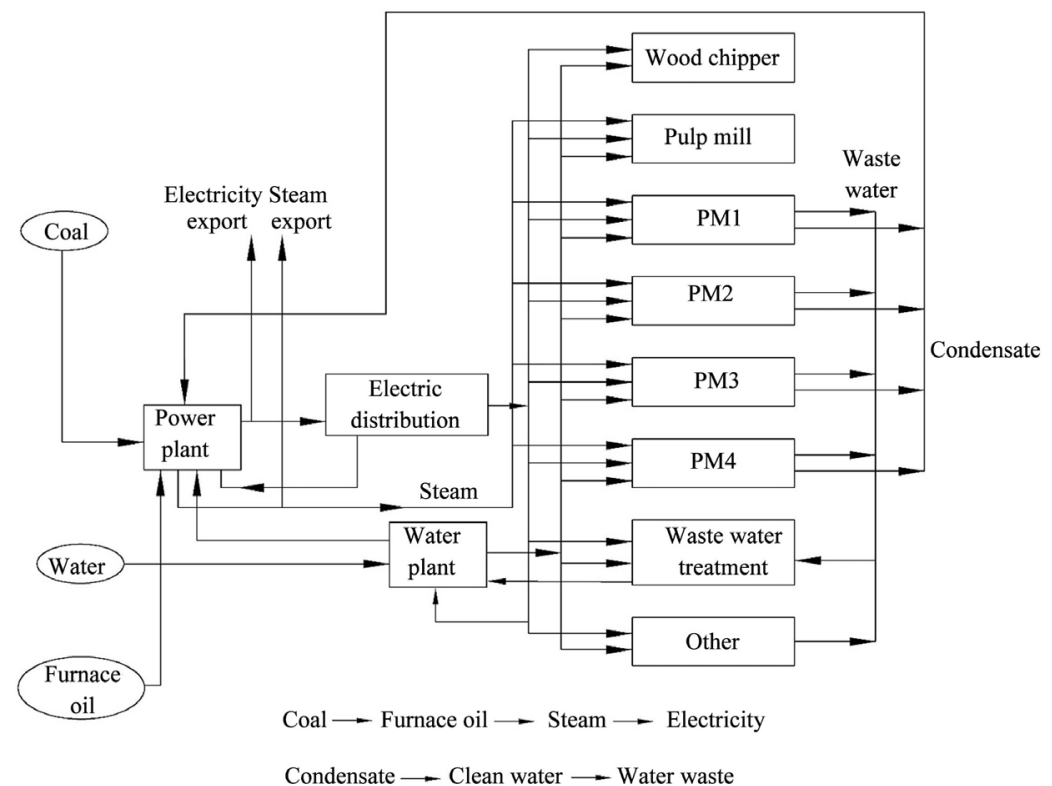

Figure 2. Energy flow diagram of the paper production plant. 


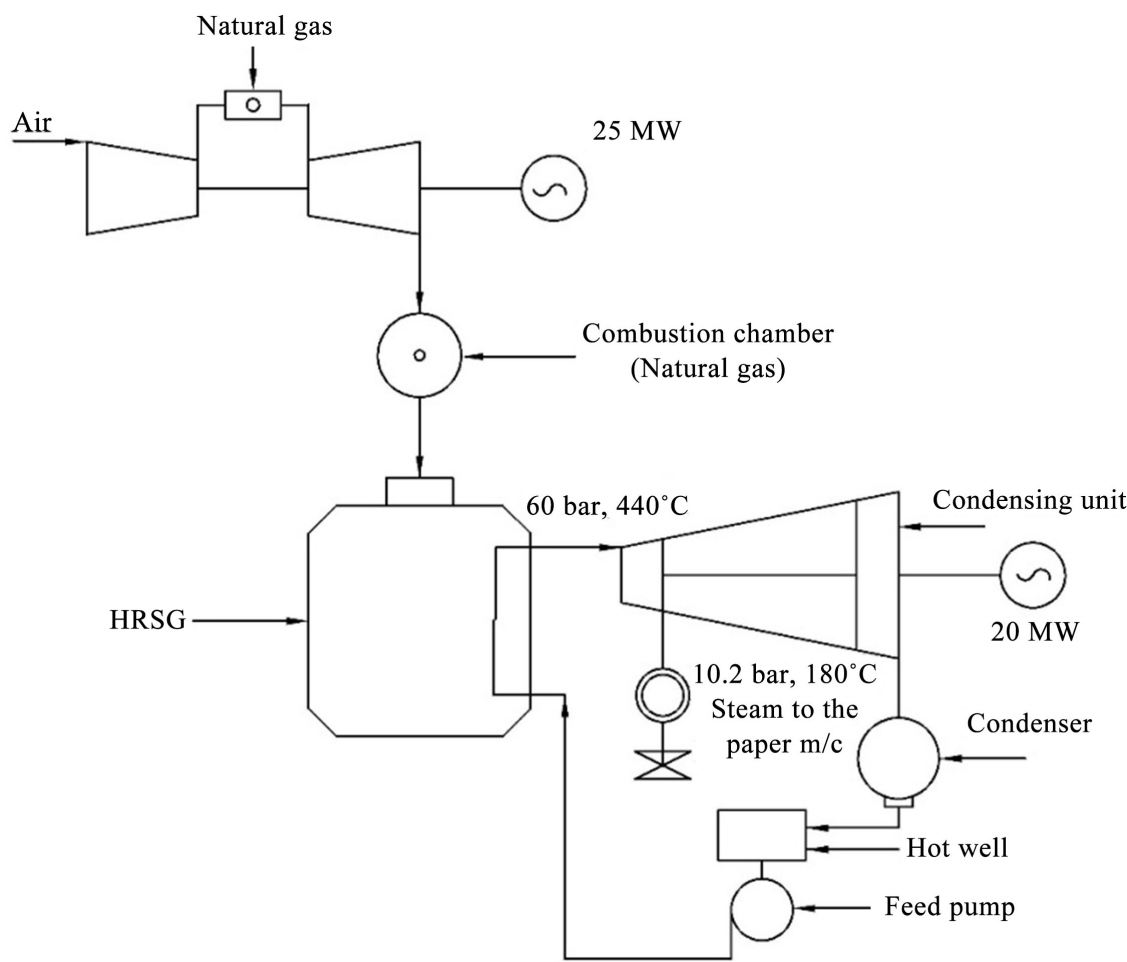

Figure 3. Proposed Combined Cycle plant with Gas turbine and pass-out steam turbine.

(Source: All the data listed in Table 3 have been taken from the OPM Data Record Center Office. As per the power purchase agreement (PPA), the electricity supply to the grid as well as to the adjacent chemical industry by OPM is estimated to be Rs. 4.50 per $\mathrm{kWh}$ ).

The thermal efficiency of the combined cycle plant was evaluated as 57\%, which is much higher than the existing steam plant efficiency of $33 \%$. The higher efficiency of such a modified plant has twin advantages: 1) reduced heat rate and thereby reduced carbon emissions 2) additional power generated and exported to the grid providing higher RVA. Further, as estimated, the investment for repowering is expected to have a payback period of less than two years, making it economically attractive for the industry.

The following data was used to evaluate the improved ISI:

$\mathrm{CV}$ of natural gas is $48 \mathrm{MJ} / \mathrm{kg}$; Specific emission factor of natural gas is $2.67 \mathrm{~kg}$ $\mathrm{CO}_{2} / \mathrm{kg}$ fuel [17].

Hence, $\mathrm{CO}_{2}$ emissions are $131,799 \mathrm{tCO}_{2}$.

RVA is about 5139 million Rs.

EMP is 2000 persons for the year 2017.

Thus, ISI for the modified system is evaluated as 78 units.

Hence, with the proposed modified system for the OPM industry, the improvement in ISI of the industry is nearly five times compared to the existing system. This huge improvement in ISI could be obtained due to simultaneous decrease in carbon emissions along with a significant increase in RVA; thereby so significantly improving the socio-economic benefit per unit of carbon emis- 
sions for the OPM industry. However, it is not possible to compare this ISI improvement with any similar index, as no such industrial sustainability index has been reported in the available literature for quantitative comparison.

\section{Conclusions}

A new holistic sustainability index (ISI) for the industrial sector was proposed, which represents the socio-economic benefit from an industry per unit of its carbon emissions. To illustrate the concept of ISI, it was evaluated for a typical paper industry in India. An improved value of such an index was obtained when the existing plant was modified to run on natural gas in place of coal and through a more efficient combined cycle plant. A significant improvement in the ISI (about five times) was observed through this modification at the system level. Such a measure is also estimated to have a payback period less than two years.

In general, many opportunities exist for improving the ISI such as process energy reduction, fuel substitution, more efficient energy supply system, energy efficient design of the factory buildings and outdoor lighting, renewable energy utilization in the form of biogas, solar photovoltaic and solar hot water systems etc. Also, suitable substitution and recycling of materials may improve the ISI. The level of ISI improvement will depend on the measures adopted based on their economic viability.

The feasibility of such modifications may be examined on a case to case basis. For example, for the pulp and paper industry, natural gas fuelled combined cycle power plant in place of the existing coal-fired plant was found to be both technically and economically viable. Further, for the manufacturing of tissue paper, the authors propose adding "neem" tree pulp (Azadirachta Indica) as a raw-material so as to reduce the bamboo/eucalyptus pulp requirement as well as to make this herbal tissue paper anti-bacterial, which may be sold at a higher price. This is likely to increase the RVA and decrease the carbon emissions, hence enhancing the ISI.

Since employment generation is a positive factor for ISI, the industries pursuing the goal of higher ISI will be discouraged to reduce employment opportunities provided by them. This would have a positive social impact. Further, the proposed ISI may be used as a policy making tool by the government to promote sustainability in the industrial sector through tax benefits, reduced interests on loans, grants etc.

\section{Acknowledgements}

The authors gratefully acknowledge the help and support received from the management of Orient Paper Mills at Amlai, Shahdol, Madhya Pradesh, India in obtaining the energy use and production data from the plant.

\section{Conflicts of Interest}

The authors declare no conflicts of interest regarding the publication of this paper. 


\section{References}

[1] Intergovernmental Panel on Climate Change "Climate Change 2014: Mitigation of Climate Change" 2014. http://www.ipcc.ch/report/ar5/wg3/

[2] International Energy Agency (2012) $\mathrm{CO}_{2}$ Emissions from Fuel Combustion. Beyond 2020 Online Database. 2012 Edition. http://data.iea.org

[3] Kuhn, T.S. (1970) The Structure of Scientific Revolutions. Chicago and London, 2nd Edition, Vol. II, University of Chicago Press, Chicago, IL.

[4] Elms, H., Brammer, S., Harris, J.D. and Phillips, R.A. (2010) New Directions in Strategic Management and Business Ethics. Business Ethics Quarterly, 20, 401-425. https://doi.org/10.5840/beq201020328

[5] Industry, Innovation and Infrastructure. https://unstats.un.org/sdgs/report/2016/goal-09/

[6] Koulton, P. (2010) Materials and Sustainable Development. Progress in Natural Science: Materials International, 20, 16-29. https://doi.org/10.1016/S1002-0071(12)60002-1

[7] Kong, L., Hasanbeigi, A. and Price, L. (2012) Emerging Energy-Efficiency and Greenhouse Gas Mitigation Technologies for the Pulp and Paper Industry. Lawrence Berkeley National Laboratory, Berkeley, CA, Report No. LBNL-5956E.

[8] Confederation of Indian Industry Technology Compendium on Energy Saving Opportunities-Pulp \& Paper.

https://shaktifoundation.in/report/technology-compendium-energy-saving-opportu nities-pulp-paper-sector/

[9] Bajpai, P. (2016) Pulp and Paper Industry: Energy Conservation. Elsevier, Amsterdam. https://doi.org/10.1016/C2014-0-02105-3

[10] Prakash, R. and Henham, A. (2014) Decentralized Energy Systems for Dairy Industry. International Journal of Environmental Sustainability, 9, 1-9. https://doi.org/10.18848/2325-1077/CGP/v09i03/55096

[11] Fiksel, J., McDaniel, J. and Spitzley, D. (1998) Measuring Product Sustainability. The Journal of Sustainable Product Design, 6, 7-19.

[12] Dickinson, D.A. and Caudill, R.J. (2003) Sustainable Product and Material End-of-Life Management: An Approach for Evaluating Alternatives. Proceedings of the IEEE International Symposium on Electronics and the Environment, Boston, MA, 19-22 May 2003, 153-158. https://doi.org/10.1109/ISEE.2003.1208065

[13] Gao, M., Zhou, M. and Wang, F. (2003) Improvement of Product Sustainability. Proceedings of the 2003 IEEE Int. Conf. on Robotics \& Automation, Taipei, 14-19 September 2003, 3548-3553.

[14] Schmidt, W.P. and Butt, F. (2006) Life-Cycle Tools within Ford of Europe's Product Sustainability Index. International Journal Life-Cycle Assessment, 11, 315-322. https://doi.org/10.1065/lca2006.08.267

[15] Ungureanu, C.A., Das, S. and Jawahir, I.S. (2007) Development of a Sustainability Scoring Method for Manufactured Automotive Products: A Case Study of Auto Body Panels. Proceedings of 2007 ASME International Mechanical Engineering Congress and Exposition, Seattle, WA, November 11-15, 2007, Paper No. IMECE2007-43818. https://doi.org/10.1115/IMECE2007-43818

[16] Sharma, S.K. (2012) Global Warming and Carbon Footprint: A New Challenge for Indian Chemical Industry. Indian Chemical Engineer, 54, 36-51. https://doi.org/10.1080/00194506.2012.730685 
[17] Intergovernmental Panel on Climate Change (2006) IPCC Guidelines for National Green House Gas Inventories. Energy, 2, 2.16-2.23.

[18] ETMARKETS The Economic Times.

https://economictimes.indiatimes.com/commoditysummary/symbol-NATURALG $\underline{\text { AS.cms }}$ 